\title{
Enhancement of Saccharification of Corn Stover by Cellulolytic Enzyme Produced from Biomass-degrading Bacteria
}

\author{
Yanwen Wu, a,b,1 Sarita Shrestha, ${ }^{\mathrm{b}, 1}$ Haipeng Guo, ${ }^{\mathrm{c}}$ Jinchi Zhang, ${ }^{\mathrm{a}, *}$ Haisong Wang, ${ }^{\mathrm{d}}$ and \\ Wensheng Qin ${ }^{\mathrm{b}, *}$
}

\begin{abstract}
Enzymatic saccharification of corn stover can be enhanced by partially replacing commercial enzymes with bacterial crude enzyme extracts. Thus, in this study, three bacteria (Bacillus sp. A0, Bacillus sp. CH20S1, and Exiguobacterium sp. AS2B) were cultured in a media with corn stover as the substrate to produce crude enzyme extract and saccharify corn stover. The cultural conditions were monitored and optimized to maximize CMCase and xylanase activity in the crude enzyme extracts. After $72 \mathrm{~h}$ of hydrolysis of corn stover with diluted crude enzymes (DCE) from the three strains, reducing sugars ranging from 48.2 to $71.7 \mathrm{mg} \mathrm{g}^{-1}$ were released from non-pretreated and pretreated corn stover. Furthermore, the maximum reducing sugars of 316 and $321 \mathrm{mg} \mathrm{g}^{-1}$ were observed when 12 and 4 FPU g ${ }^{-1}$ of commercial cellulase were added to the DCE of the $\mathrm{CH} 20 \mathrm{~S} 1$ strain, respectively. It was shown that an effective combination of bacterial DCE with commercial enzymes could achieve higher saccharification of lignocellulosic biomass, which might be cost-efficient compared to their single-use. Overall, this study aims to show the enhanced enzymatic saccharification of corn stover.
\end{abstract}

DOI: 10.15376/biores.17.1.1301-1318

Keywords: Enzymes; Cellulase; Saccharification; Synergistic effect

Contact information: a: Collaborative Innovation Center of Sustainable Forestry in Southern China of Jiangsu Province, Nanjing Forestry University, Nanjing 210037, China; b: Department of Biology, Lakehead University, Thunder Bay, ON, P7B 5E1, Canada; c: School of Marine Sciences, Ningbo University, Ningbo 315211, China; d: School of Light Industry and Chemical Engineering, Dalian Polytechnic University, Dalian 116034, Liaoning, China; ${ }^{1}$ : Authors contributed equally to this work;

*Corresponding authors: zhang8811@njfu.edu.cn; wqin@lakeheadu.ca

\section{INTRODUCTION}

Lignocellulosic biomass is used as an inexpensive green renewable resource for producing different value-added products. However, the different components present in lignocellulosic biomasses contribute to the recalcitrant properties of biomasses and are resistant to enzymatic and chemical degradation (Isikgor and Becer 2015; Sun et al. 2016; Shrestha et al. 2020). Thus, pretreatment is preferred as an essential step in breaking down cell walls and causing the efficient release of fermentable sugars from various lignocellulosic biomass that further can be used for producing other valuable products such as bioethanol (Rajendran et al. 2018). Numerous pretreatment technologies such as alkaline, ammonia, dilute acid, and steam explosion pretreatment have been developed to solve the biomass recalcitrance problem for efficient enzymatic saccharification. However, harsh pretreatment can lead to the degradation of sugars, while too weak pretreatment results in low enzyme accessibility (Chaturvedi and Verma 2013; Rajendran et al. 2018). Although the biomass composition plays a crucial role in the outcome of pretreatment, the 
enzymatic hydrolysis after different physical or chemical pretreatment may be beneficial economically (Hendriks and Zeeman 2009; Chapla et al. 2010). In addition, the pretreatment facilitates conversion efficiency by destroying or breaking down the initial structure of the biomass (Sun et al. 2016; Zhang et al. 2021a). Thus, in this study, corn stover was used as biomass and pretreatment via alkaline hydrogen peroxide (AHP) and dilute acid was evaluated, followed by enzymatic saccharification.

Corn stover was used in this study as it is one of the most widely used renewable energy sources in bioconversion. AHP and dilute acid hydrolysis have been widely used to enhance the conversion of corn stover because the component fractions of corn stover can be efficiently hydrolyzed into monomeric components by using those two methods. Therefore, the conversion and enzyme accessibility can be highly improved (Akhlisah et al. 2021). However, due to problems such as high equipment requirements, different degrees of corrosion, and environmental pollution, there is still room for improvement in these two methods.

Enzymatic hydrolysis is the best method for subsequent fermentation because of its high specificity, high yield, and lower formation of undesirable products (Ostadjoo et al. 2019; Shrestha et al. 2020). Cellulases and xylanases are the important enzymes for the hydrolysis of cellulose and hemicellulose contained in the various biomasses (Prajapati et al. 2018; Shrestha et al. 2020). Hence, the improvement of cellulolytic microorganisms and enhancement of the hydrolytic capacity of cellulases are essential. This study aimed to study the saccharification of corn stover by bacterial cellulolytic enzymes for cost reduction because the majority of studies have focused on fungal cellulolytic enzymes (Zhang et al. 2014; Ferraz et al. 2018). Bacteria are considered more appropriate to produce the hydrolytic enzymes for saccharification on an industrial scale due to the shorter generation time, ability to be artificially cultivated (Sadhu and Maiti 2013), and excellent tolerance to environmental stresses (Vilanova et al. 2012; Thatoi et al. 2014).

The present research concentrated on three bacterial strains (A0, AS2B, and $\mathrm{CH} 20 \mathrm{~S} 1$ ) to produce cellulolytic enzymes using corn stover as the substrate and to examine the possibility of bacterial enzymes in the saccharification process. The hydrolytic efficiency of the crude enzyme extracts from the studied strains was evaluated from saccharification assays measuring the reducing sugars released from pretreated and nonpretreated corn stover. Finally, the crude enzyme extract from the best saccharifying strain was selected and combined with commercial enzymes in different concentrations to study the saccharification efficiencies.

\section{EXPERIMENTAL}

\section{Biomass Material and Bacterial Strains}

The bacteria Bacillus sp. A0 (Accession no. KP974676), Bacillus sp. CH20S1 (Accession no. HQ331531), and Exiguobacterium sp. AS2B (Accession no. HM134063) used in this study were isolated from rotting wood samples, municipal waste, and peat. They were stored at $-80^{\circ} \mathrm{C}$ in the authors' lab. Their enzymatic characteristics have already been reported (Maki et al. 2012; Paudel et al. 2015; Guo et al. 2017). All the strains stored at $-80{ }^{\circ} \mathrm{C}$ were activated by culturing in Luria-Bertani (LB) medium $\left(37^{\circ} \mathrm{C}, 200 \mathrm{rpm}\right)$ for $12 \mathrm{~h}$ before the experiments. The corn stover containing high contents of glucan and xylan was chosen to induce cellulolytic enzymes from the three strains. The untreated corn stover was dried at $50{ }^{\circ} \mathrm{C}$ until a constant weight was attained, cut into small $(2$ to $5 \mathrm{~cm})$ pieces, 
and then ground through a 50-mesh sieve. The corn stover was provided by Agriculture and Agri-Food Canada (Ottawa, Canada).

\section{Pretreatment}

Prior to the enzymatic hydrolysis of corn stover, it was subjected for pretreatments (AHP pretreatment and $\mathrm{H}_{2} \mathrm{SO}_{4}$ pretreatment) to enhance the enzymatic hydrolysis efficiency by changing the structure of corn stover.

\section{AHP pretreatment}

This pretreatment method followed the method reported by Banerjee et al. (2011) with slight modification. In brief, $30 \%$ (w/v) $\mathrm{H}_{2} \mathrm{O}_{2}(\mathrm{pH}$ to 11.5 adjusted with $2.0 \mathrm{M} \mathrm{NaOH})$ was mixed with $5 \%(\mathrm{w} / \mathrm{v})$ of milled corn stover samples and was shaken at $150 \mathrm{rpm}$ at 50 ${ }^{\circ} \mathrm{C}$ for $1 \mathrm{~h}$. After $1 \mathrm{~h}$, the mixture was centrifuged to obtain the solid and liquid fractions. The solid fraction was washed with deionized water until $\mathrm{pH} 7$, dried in an oven at $80{ }^{\circ} \mathrm{C}$ overnight, and used for composition analysis.

\section{$\mathrm{H}_{2} \mathrm{SO}_{4}$ pretreatment}

Acid pretreatment was conducted as described by Xu et al. (2012) with some minor modifications. In brief, $0.5 \mathrm{~g}$ of biomass samples were mixed with $10 \mathrm{~mL} \mathrm{H}_{2} \mathrm{SO}_{4}(1 \%$, v/v) in $15 \mathrm{~mL}$ plastic centrifuge tubes, and autoclaved at $121^{\circ} \mathrm{C}$ for $20 \mathrm{~min}$. After cooling down, the tubes were shaken at $150 \mathrm{rpm}$ and $50{ }^{\circ} \mathrm{C}$ for $2 \mathrm{~h}$, then centrifuged at $3,000 \mathrm{~g}$ for $5 \mathrm{~min}$. The residues were washed with deionized water until neutral $\mathrm{pH}$ of the washing fluid and finally dried at $80{ }^{\circ} \mathrm{C}$ overnight for plant cell wall composition analysis.

\section{Biomass Composition Analysis}

The biomass composition analysis was performed as mentioned in Wu et al. (2021), in which cellulose and hemicellulose were analyzed by measuring the glucan and xylan contents. The Klason lignin analysis was performed by anthrone-sulfuric acid and orcinolhydrochloric acid methods.

\section{Obtaining Crude Enzymes and Enzyme Assay}

Each strain was inoculated $(2 \%, \mathrm{v} / \mathrm{v})$ in $50 \mathrm{~mL}$ of mineral salt medium (consisting of $1.0 \mathrm{~g} \mathrm{~L}^{-1} \mathrm{NaNO}_{3}, 1.0 \mathrm{~g} \mathrm{~L}^{-1} \mathrm{~K}_{2} \mathrm{HPO}_{4}, 1.0 \mathrm{~g} \mathrm{~L}^{-1} \mathrm{KCl}_{3} 3.0 \mathrm{~g} \mathrm{~L}^{-1}$ peptone, $0.5 \mathrm{~g} \mathrm{~L}^{-1} \mathrm{MgSO}_{4}$, and $0.5 \mathrm{~g} \mathrm{~L}^{-1}$ yeast extract) containing $0.5 \%(\mathrm{w} / \mathrm{v})$ non-pretreated corn stover. The media contained only corn stover as the sole carbon source. The samples were incubated at $37{ }^{\circ} \mathrm{C}$, $200 \mathrm{rpm}$, and for 6 days. After harvesting the culture, the samples were centrifuged at $12,000 \mathrm{~g}$ for $3 \mathrm{~min}$. Then the supernatants as crude enzymes were processed for sterile filtration using a $0.22-\mu \mathrm{m}$ Millipore filter (Billerica, MA, USA). In addition, the supernatants were used for the analysis of xylanase and CMCase activity. The supernatant solutions with maximum CMCase and xylanase were later used for the hydrolyzing experiments. The CMCase and xylanase activities were determined by DNS methods (Miller 1959), where the reducing sugars released from CMC and xylan were calculated as described by Guo et al. (2017).

\section{Influences of Temperature and pH on Enzyme Activities}

The effects of temperature ( 40 to $80{ }^{\circ} \mathrm{C}$ with $5{ }^{\circ} \mathrm{C}$ intervals) and the influence of $\mathrm{pH}$ (4 to 8 with 0.5 intervals) on enzyme activities were studied. The buffer solutions, 0.05 $\mathrm{M}$ citrate buffer for $\mathrm{pH} 4$ to 7 and $0.05 \mathrm{M}$ Tris- $\mathrm{HCl}$ buffer for $\mathrm{pH} 7.8$ to 8.0, were used in 
maintaining different $\mathrm{pH}$ for enzyme activities. The enzyme activities were calculated as relative activity. The relative activity is the ratio of activity at a certain time by activity at an initial time multiplied by 100 , which is as,

$$
\text { Relative activity }(\%)=\frac{A_{t}}{A_{\mathrm{o}}} \times 100 \%
$$

where $A_{t}$ is the enzyme activity at time equal to $t$ and $A_{\mathrm{o}}$ is the initial enzyme activity.

\section{Enzymatic Saccharification}

Enzymatic saccharification of corn stover using different strains

For enzymatic saccharification of corn stover, crude enzyme extracts obtained from three bacterial strains A0, CH20S1, and AS2B were used. For each pretreated corn stover, $3.5 \mathrm{~mL}$ of crude enzyme extract was added after adjusting $\mathrm{pH}$ of 5 with $0.05 \mathrm{M}$ sodium citrate buffer ( $\mathrm{pH}$ 5). The reaction mixture was incubated at $55^{\circ} \mathrm{C}$ with an agitation of 200 rpm for $72 \mathrm{~h}$. The supernatants were collected every $12 \mathrm{~h}$ to determine the amount of reducing sugars. Also, $5.0 \mathrm{~mL}$ of diluted crude enzymes (DCE) solution without any treatment was set as the control.

Combined effect of commercial cellulase and crude enzyme for saccharification of corn stover

A commercial cellulase (Celluclast 1.5 L, Novozymes, Franklinton, NC, USA) from Trichoderma reesei ATCC 26921 was used in this study. The crude enzyme produced from strain $\mathrm{CH} 20 \mathrm{~S} 1$ was combined with commercial cellulase in three sets: $5.0 \mathrm{~mL}$ of DCE were added to 4,8 , and $12 \mathrm{FPU} \mathrm{g}^{-1}$ dry biomass of commercial cellulase to study enzymatic saccharification of corn stover. Also, the control group contained 20 FPU g ${ }^{-1}$ of commercial cellulase without the crude enzyme extract, with reference to the previous report by Singh et al. (2009).

\section{Statistical Analysis}

The statistical analysis was carried out by one-way analysis of variance (one-way ANOVA) using SPSS (version 13.0, SPSS Inc., Chicago, IL, USA). The data were taken in triplicate and the values mentioned as mean \pm standard deviation.

\section{RESULTS AND DISCUSSION}

\section{Characterization of Corn Stover Before and After Pretreatments}

The effects of pretreatments including AHP and $\mathrm{H}_{2} \mathrm{SO}_{4}$ on the corn stover and the differences in the content's compositions (glucan, xylan, and lignin) of the pretreated corn stover are shown in Table 1. The result illustrated that both pretreatments were able to change the cell wall composition of corn stover. It is known that different pretreatment methods improve the hydrolysis of biomass and change the chemical and physical structures of biomass resulting in enzymes accessibility to corn stover and yielding of fermentable sugars (Sun et al. 2016; Avci et al. 2019). 
Table 1. Composition of Corn Stover Expressed as Percentage of Dry Matter

\begin{tabular}{|c|c|c|c|}
\hline \multirow{2}{*}{ Pretreatment } & \multicolumn{3}{|c|}{ Component (\%) } \\
\cline { 2 - 4 } & Glucan & Xylan & Acid insoluble lignin \\
\hline Non-pretreated & $27.4 \pm 0.5^{\mathrm{c}}$ & $18.9 \pm 1.1^{\mathrm{a}}$ & $21.1 \pm 1.5^{\mathrm{b}}$ \\
\hline AHP & $41.0 \pm 4.9^{\mathrm{b}}$ & $20.7 \pm 0.3^{\mathrm{a}}$ & $15.5 \pm 0.9^{\mathrm{c}}$ \\
\hline $\mathrm{H}_{2} \mathrm{SO}_{4}$ & $53.7 \pm 3.3^{\mathrm{a}}$ & $16.7 \pm 0.8^{\mathrm{b}}$ & $27.9 \pm 0.6^{\mathrm{a}}$ \\
\hline
\end{tabular}

Different letters indicate significant differences $(\mathrm{P}<0.05)$ among different pretreatments

The corn stover used as a raw material revealed acid-insoluble lignin $21.1 \%$ and glucan and xylan of $27.4 \%$ and $18.9 \%$ respectively. Besides, there are other carbohydrates and components present in corn stover that are not described in Table 1. This result was found to be consistent with that of the corn stover analyzed in another study (Liu et al. 2013). Also, the contents of corn stover were observed to be almost in the range mentioned; cellulose 30 to $60 \%$, hemicellulose 20 to 40\%, and lignin 15 to 25\% (Dahadha et al. 2017; Avci et al. 2019). After the AHP treatment, the content of lignin was $15.5 \%$, which showed a significant reduction compared to the raw material $(\mathrm{P}<0.05)$, while the glucan content increased significantly by $49.6 \%$ with a minor increase of xylan. However, $1 \% \mathrm{H}_{2} \mathrm{SO}_{4}$ pretreatment resulted in a significant increase of glucan content $(53.7 \%, \mathrm{P}<0.05)$ compared to that of the raw material, and the xylan content significantly decreased to $16.7 \%(\mathrm{P}<0.05)$ (Table 1). The alkali assisted acidic pretreatment in another study has determined $59.5 \%, 5.2 \%$, and $8.3 \%$ of cellulose, lignin, and hemicellulose, respectively (Goyal et al. 2014). The alkali pretreatment removes most of the lignin by dissolving lignin as a result of breaking ether linkages, hydrogen bonds, and other covalent bonds, leaving behind a highly porous cell wall for better penetration of enzymes (Chaturvedi and Verma 2013; Goyal et al. 2014; Sun et al. 2016). In contrast, acid $\left(\mathrm{H}_{2} \mathrm{SO}_{4}\right)$ pretreatment mainly induces the hydrolysis of cellulose and hemicellulose, produces monomeric sugars (Chaturvedi and Verma 2013), and hence the monomeric sugars are removed from the biomasses after pretreatment. Thus, the non-pretreated corn stover had higher xylan content compared to acid-pretreated corn stover. Furthermore, the concentrations of chemicals used and time of treatment also play a major role in determining the biomass contents (Mensah et al. 2021).

\section{Production of CMC and Xylan Hydrolysing Enzymes}

When three bacterial strains (A0, CH20S1, and AS2B) were cultured in the media containing corn stover as only carbon source, they exhibited an excellent CMCase and xylanase. Also, the enzyme activities by these strains were produced in a similar variation tendency (Fig. 1). The majority of CMCase and xylanase were secreted into the medium in $12 \mathrm{~h}$ of incubation period for all tested strains. The highest CMCase activities for A0, CH20S1, and AS2B were 2.1, 1.9, and $2.6 \mathrm{U} \mathrm{mL}^{-1}$, respectively (Fig. 1a). Similarly, the maximum corresponding xylanase activities were $20.3,29.4$, and $26.7 \mathrm{U} \mathrm{mL}^{-1}$, respectively (Fig. 1b). In another study, different biomasses including algae, wheat bran, agave, corn stover, wood dust, CMC, and pine chip were used for enzymes production. Moreover, the study revealed Bacillus sp. produced maximum CMCase $\left(17.8 \mathrm{U} \mathrm{g}^{-1}\right)$ and xylanase (195.8 $\left.\mathrm{U} \mathrm{g}^{-1}\right)$ from corn stover $(0.5 \% \mathrm{w} / \mathrm{v})$ among the various biomasses and they used corn stover for further study (Wu et al. 2021).

Both CMCase and xylanase activity increased continuously until $12 \mathrm{~h}$ of incubation because the strains in this study had suitable cultural conditions and nutrients for their enzymatic activities. However, activities decreased rapidly after reaching peak values at 
$12 \mathrm{~h}$, possibly because the substrate may have been used up, or maybe there was change in pH making unfavorable conditions, or some inhibiting products may have been produced in the media. The maximum CMCase activity (1.9 to $\left.2.6 \mathrm{U} \mathrm{mL}^{-1}\right)$ and xylanase activity (29.4 $\mathrm{U} \mathrm{mL}^{-1}$ ) of these three strains studied here were all remarkably higher than the previously reported typical cellulase-producing Bacillus sp. strain (Kim et al. 2012). The maximum xylanase $\left(7.9 \mathrm{U} \mathrm{mL}^{-1}\right)$ was produced from Bacillus pumilus under optimized condition. Xylanase in that manner has the potential to be useful in paper and pulp industries (Lawrence et al. 2015). The results indicate that corn stover containing rich cellulose and hemicellulose could effectively induce the production of cellulolytic and hemicellulolytic enzymes in bacteria. In addition, the combined effect of xylanase and cellulase are more effective in the degradation of lignocellulosic biomass (Prajapati et al. 2018).
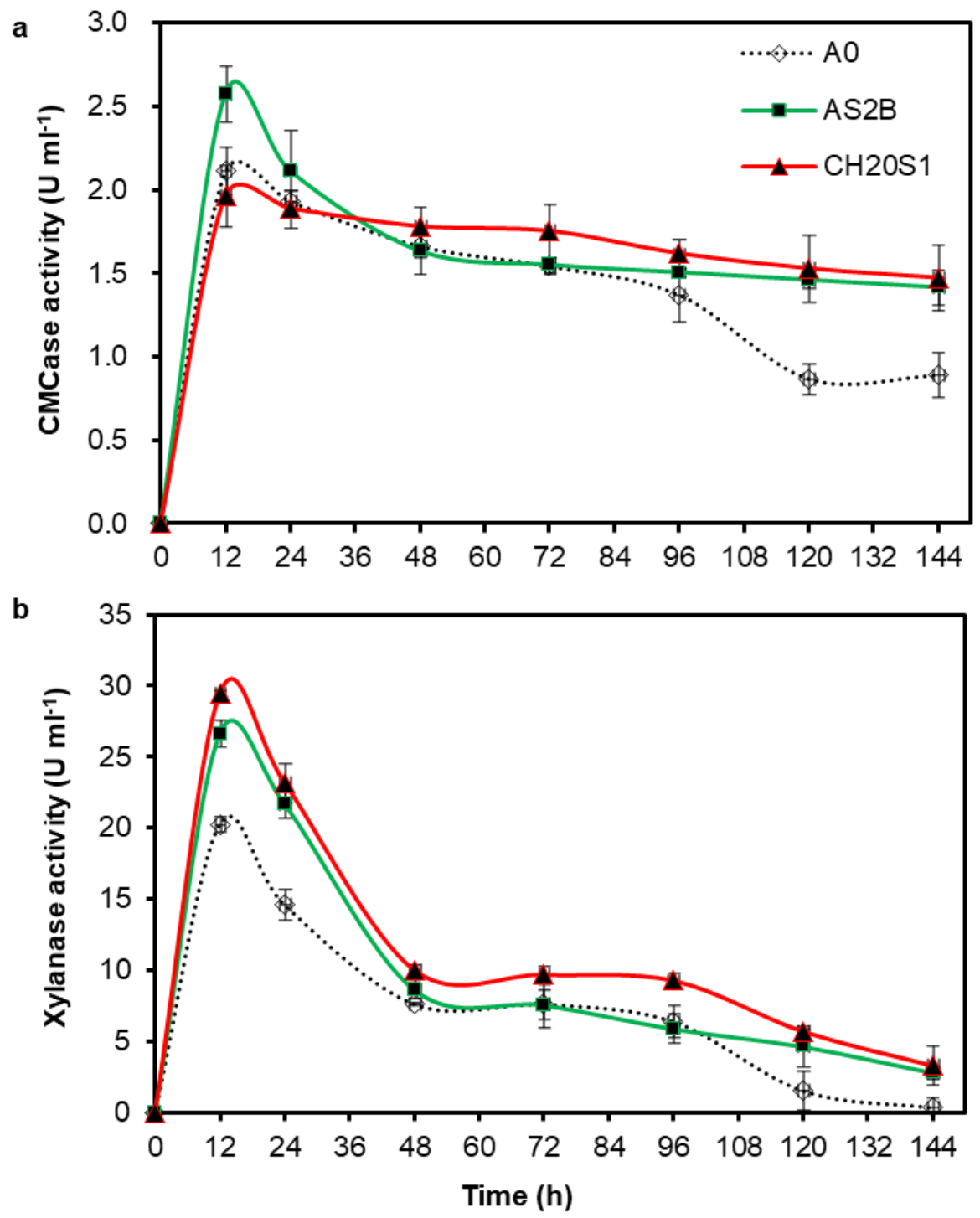

Fig. 1. CMCase (a) and xylanase (b) activity in strains $A 0, A S 2 B$, and $\mathrm{CH} 20 \mathrm{~S} 1$ using non pretreated corn stover as the substrate in submerged fermentation with shaking for $144 \mathrm{~h}$ at 37 ${ }^{\circ} \mathrm{C}$. Bars indicate the standard deviation $(\mathrm{n}=3)$. The symbol * indicates a significant difference at $P<0.05$. 


\section{Optimal Temperature and pH for Enzymatic Activities}

The best hydrolytic performance of enzymes is affected by the optimal temperature and $\mathrm{pH}$. Thus, the enzymes produced by these three strains were employed in further tests to determine the influence of temperature and $\mathrm{pH}$ on enzyme activity. The optimal temperature for maximum CMCase activities was $55^{\circ} \mathrm{C}$ exhibited by $\mathrm{AS} 2 \mathrm{~B}, \mathrm{~A} 0$, and $\mathrm{CH} 20 \mathrm{~S} 1$ strains. However, the optimal temperatures for xylanase activity were 50, 60, and $60{ }^{\circ} \mathrm{C}$ for the mentioned strains, respectively (Fig. 2).
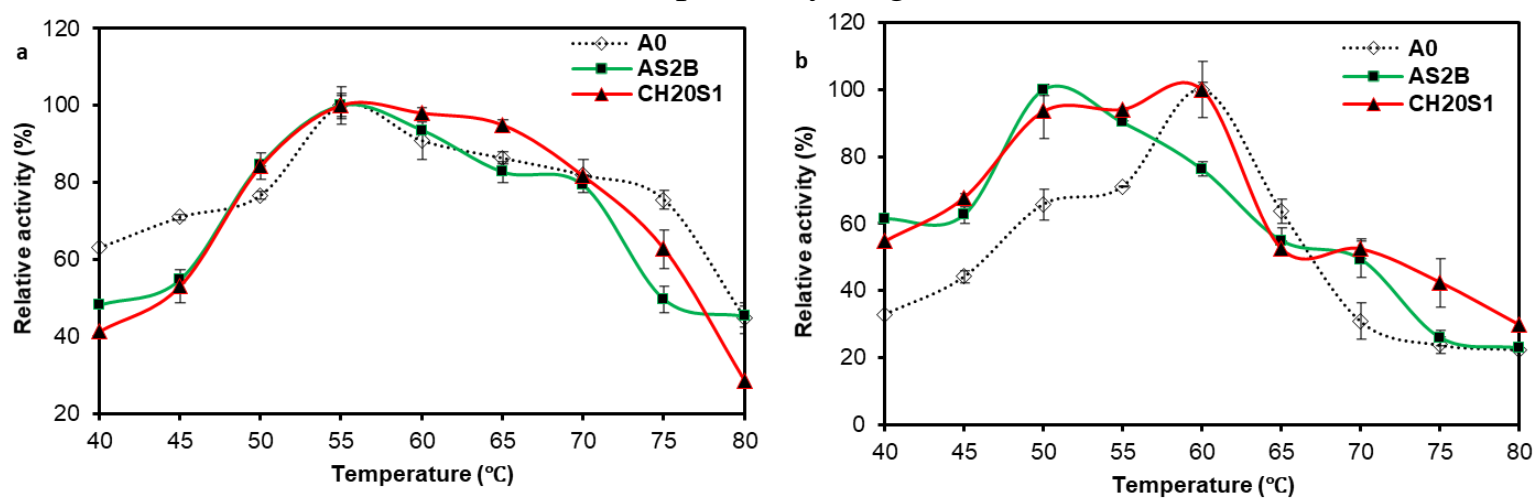

Fig. 2. Effects of different temperatures on CMCase (a) and xylanase (b) activity. The temperature for enzymatic activities ranges from $40^{\circ} \mathrm{C}$ to $80^{\circ} \mathrm{C}$, and bars indicate the standard deviation $(n=3)$.

The CMCase and xylanase activities were observed to be maximum at $\mathrm{pH} 5.5$ for A0 strain, $\mathrm{pH} 5.0$ for AS2B, while $\mathrm{pH} 5$ to $\mathrm{pH} 6$ was optimal $\mathrm{pH}$ for $\mathrm{CH} 20 \mathrm{~S} 1$ strain (Fig. $3)$. The $\mathrm{pH}$ and temperature play an important role, affecting the metabolic rate and growth of bacteria. The optimal $\mathrm{pH}$ and temperature differ with different fermentation conditions and strains. Lawrence et al. (2015) demonstrated $\mathrm{pH} 7$ and $50{ }^{\circ} \mathrm{C}$ as the optimum $\mathrm{pH}$ and temperature for Bacillus pumilus to produce xylanase. Similarly, another study revealed $\mathrm{pH} 7$ and $37^{\circ} \mathrm{C}$ were the optimum $\mathrm{pH}$ and temperature for Bacillus pumilus (Kaur et al. 2017).
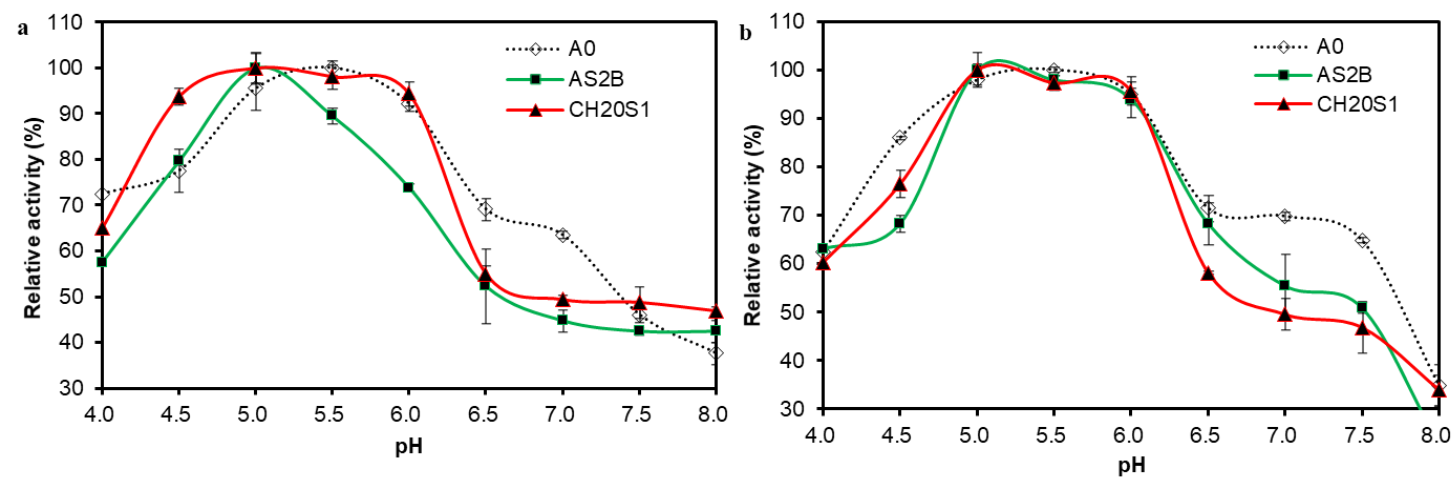

Fig. 3. Effects of $\mathrm{pH}$ on $\mathrm{CMCase}(\mathrm{a})$ and xylanase (b) activity. The $\mathrm{pH}$ for enzymatic activities ranges from 4 to 8 , and bars indicate the standard deviation $(n=3)$. 


\section{Bacterial Crude Enzyme Extracts and Saccharification of Corn Stover}

The crude enzymes extracted from the three strains exhibited different yields of reducing sugars from pretreated and non-pretreated corn stover (Fig. 4). After $72 \mathrm{~h}$ of incubation, the DCE from the A0 strain hydrolyzed AHP and $\mathrm{H}_{2} \mathrm{SO}_{4}$ pretreated and nonpretreated corn stover, and produced 63.3, 53.2, and $48.2 \mathrm{mg} \mathrm{g}^{-1}$ reducing sugars, respectively. Similarly, strain AS2B released 70.4, 53.9, and $52.3 \mathrm{mg} \mathrm{g}^{-1}$ reducing sugars, respectively, and another strain $\mathrm{CH} 20 \mathrm{~S} 1$ produced reducing sugars of 71.7, 63.9, and 55.2 $\mathrm{mg} \mathrm{g}^{-1}$, respectively (Fig. 4). When comparing these three strains, $\mathrm{CH} 20 \mathrm{~S} 1$ demonstrated an advantage of hydrolytic ability relative to $\mathrm{AHP}$ and $\mathrm{H}_{2} \mathrm{SO}_{4}$ pretreated and non-pretreated corn stover, releasing the highest amount of reducing sugars.
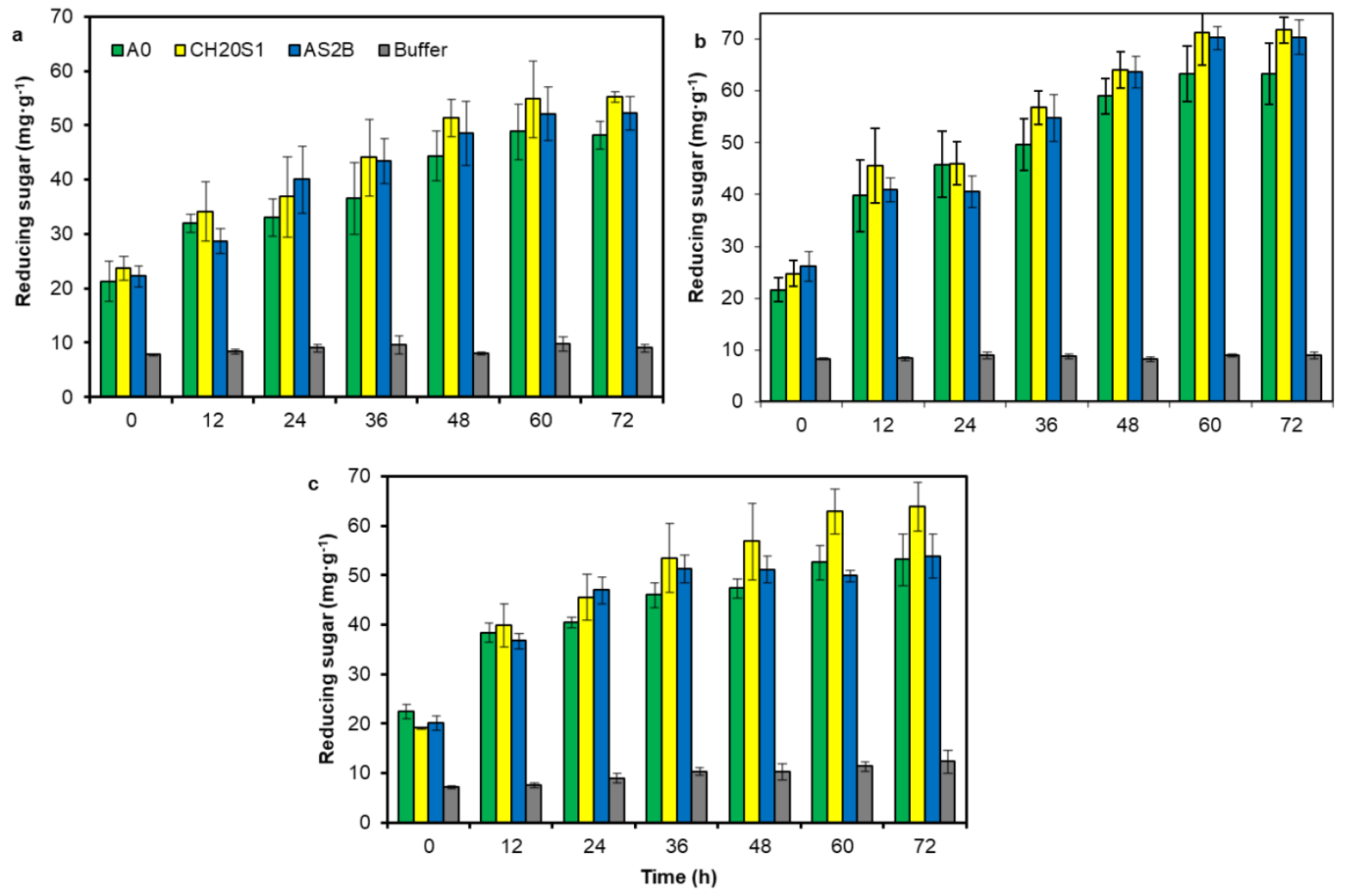

Fig. 4. Saccharification of non-pretreated (a), AHP pretreated (b), and $\mathrm{H}_{2} \mathrm{SO}_{4}$ pretreated (c) corn stover using crude enzymes produced by strains $\mathrm{A} 0, \mathrm{AS} 2 \mathrm{~B}$, and $\mathrm{CH} 20 \mathrm{~S} 1$. Saccharification was performed at $55^{\circ} \mathrm{C}, \mathrm{pH} 5.0$, with $200 \mathrm{rpm}$ for $72 \mathrm{~h}$, using a substrate concentration of $1 \%$. Bars indicate the standard deviation $(n=3)$.

The hydrolysis effects on pretreated materials were superior to non-pretreated materials, mainly because of the fiber exposure of the materials after pretreatments (Dutra et al. 2018). Moreover, the yields of reducing sugars released by DCE were 3.3 to 7.0 fold higher than that of the blank (Fig. 4), showing that the bacterial enzymes supplementation can significantly improve the hydrolysis of corn stover. However, according to previous research, the contents of reducing sugars released from non-pretreated/pretreated corn stover by commercial cellulase ranged from 100 to $400 \mathrm{mg} \mathrm{g}^{-1}$ (Li et al. 2011), which is higher than the results of this study. Similarly, enzymatic hydrolysis and alkali 
pretreatment of corn stover produced in Ghana yielded $158 \mathrm{mg} \mathrm{mL}^{-1}$ reducing sugar in 24 hours (Mensah et al. 2021).

Several enzymes and other accessory enzymes cut off the bonded side groups from the main chain, for example $\beta$-xylosidases, and endoxylanases hydrolyse the side group from the primary main structure of substituted xylan (Kocabaş et al. 2015). Further cellulolytic enzymes from bacteria can hydrolyze CMC into reducing sugars, and the hydrolytic efficiency is dependent on types of lignocellulosic biomasses (substrates) used (Sadhu and Maiti 2013; Prajapati et al. 2018; Shrestha et al. 2020). Furthermore, the types and activities of enzymes induced by different biomasses differ greatly (Maki et al. 2012). So, it can perhaps be concluded that the remarkable different hydrolysis effects between the crude bacterial enzymes and commercial cellulase studied here could be due to the lack of some essential hydrolytic enzymes in bacterial enzyme extract for lignocellulosic biomass hydrolysis effectively.

\section{Comparison of Commercial Cellulase and Crude Enzymes Effects on Saccharification}

To further explore the possibility of the practical application of bacterial enzymes in the industries, more enzymatic saccharification experiments were performed by partially replacing commercial cellulase with bacterial enzyme extracts. Strain $\mathrm{CH} 20 \mathrm{~S} 1$ showed the highest hydrolysis of corn stover, so this strain was selected among the three strains studied. For each treatment, $5.0 \mathrm{~mL}$ of DCE was added, but the reducing sugar yields for each group were noticeably different (Fig. 5). Since DCE was obtained from the supernatant of bacterial culture, in which corn stover was used as the sole carbon source for the growth of bacteria, there was small amount of reducing sugar existing in DCE on day 0 (Fig. 5).

After $72 \mathrm{~h}$ of incubation, the contents of reducing sugars released from nonpretreated, AHP pretreated, and $\mathrm{H}_{2} \mathrm{SO}_{4}$ pretreated corn stover by using $20 \mathrm{FPU} \mathrm{g}{ }^{-1}$ of commercial cellulase were $162.2,260.1$, and $317.6 \mathrm{mg} \mathrm{g}^{-1}$, respectively. The other treatments such as the addition of different concentrations of commercial cellulase and reducing sugar yields are depicted in Fig. 5. The maximum amount of reducing sugars obtained from non-pretreated raw materials was almost the same as that of the pretreated corn stover, which demonstrated that these treatments were efficient in the hydrolysis of corn stover with or without pretreatment. Furthermore, the reducing sugars produced by the addition of commercial cellulase were significantly higher than the reducing sugar produced by using the crude enzymes from bacteria. This fact confirmed the current authors' previous hypothesis that the crude enzyme extracts lack the necessary hydrolytic enzymes, which might be supplemented by commercial cellulase. In addition, the enzymes effectively need to bind with the substrates for their hydrolysis. Besides, there might be other essential proteins or other compounds that help to loosen the structures of substrates and enhance the enzymes efficiency. For example, expansin has been found to enhance the enzyme adsorption for cellulose hydrolysis (Zhang et al. 2021b).

More importantly, for AHP-pretreated corn stover, treatments using commercial cellulase with crude enzymes generally exhibited superior hydrolysis effects compared to the treatment using $20 \mathrm{FPU} \mathrm{g}^{-1}$ of commercial cellulase only. In addition, the content of reducing sugar released by commercial cellulase added to DCE declined, showing the negative relationship between the concentration of commercial cellulase addition and the released reducing sugar for AHP treated corn stover (Fig. 5b). The study described alkaline pretreatment removed lignin and increased cellulose hydrolysis (Sun et al. 2016), but 
higher loading of commercial enzyme did not increase the reducing sugars. The excess enzyme might restrict the increase of initial rate and diffusion because the excess enzyme gets adsorbed in the substrate surface (Martín et al. 2012). These results illustrate a cooperative effect of bacterial enzyme extract addition to replace the commercial cellulase partially for enzymatic hydrolysis of pretreated (AHP) corn stover.
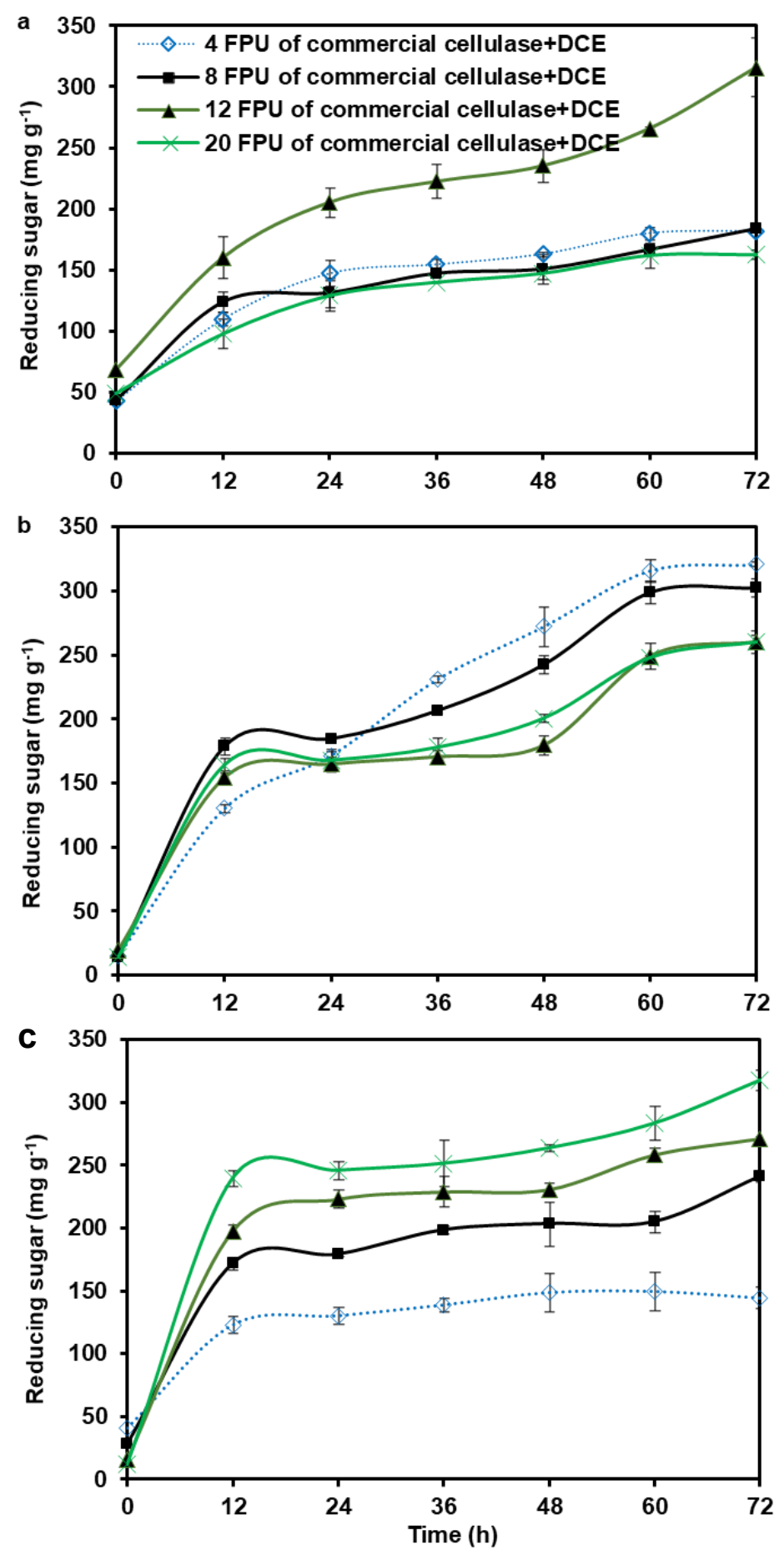

Fig. 5. Saccharification of non-pretreated (a), AHP pretreated (b), and $\mathrm{H}_{2} \mathrm{SO}_{4}$ pretreated (c) corn stover using bacterial enzyme extracts with different additions of commercial cellulases. Saccharification was performed at $55^{\circ} \mathrm{C}, \mathrm{pH} 5.0$, with $200 \mathrm{rpm}$ for $72 \mathrm{~h}$, using a substrate concentration of $1 \%$. Bars indicate the standard deviation $(n=3)$. 
According to the previous research, the non-hydrolytic protein isolated from fresh corn stover substantially increased both the hydrolysis rate of cellulose and the yield of reducing sugar (Hu et al. 2013). Also, the non-hydrolytic proteins deactivate the enzyme function and make accessibility easy for cellulolytic enzyme by loosening the highly ordered and tightly packed region of cellulose (Arantes and Saddler 2010). The nonhydrolytic proteins present in water-soluble extracts of wheat straw have a promotional effect on the enzymatic hydrolysis of pretreated wheat straw. The synergistic effect found in this study could therefore possibly have been caused by the non-hydrolytic proteins contained in the crude enzyme extracts produced by strain $\mathrm{CH} 20 \mathrm{~S} 1$ when corn stover was used as a carbon source. A similar synergistic effect was observed for non-pretreated corn stover, as shown in (Fig. 5a), where the synergistic effect increased with the increase in commercial cellulase concentration. It was observed in $72 \mathrm{~h}$ of incubation that the yields of reducing sugars were $181.7,183.6$, and $315.9 \mathrm{mg} \mathrm{g}^{1}$ when DCE of non-pretreated corn stover contained 4,8 , and $12 \mathrm{FPU} \mathrm{g}^{-1}$ of commercial cellulase, respectively. The main reason for this increase could be due to the undamaged cell wall structure of non-pretreated corn stover requiring more hydrolytic enzymes than pretreated corn stover (Banerjee et al. 2011). In addition, the bacterial enzymes showed continuous increase in the release of reducing sugar when commercial cellulase was added to $\mathrm{H}_{2} \mathrm{SO}_{4}$ pretreated corn stover used as the substrate (Fig. 5c). The $\mathrm{H}_{2} \mathrm{SO}_{4}$ pretreatment might increase the susceptibility of substrate for enzymatic hydrolysis and promote deactivation of inhibitory proteins (Jönsson and Martín 2016). However, the pretreatment might interfere with the $\mathrm{pH}$, resulting in the conformation change of corn stover and decreased in enzymatic activity. The combined pretreatment strategies could be considered as a means to achieve effective digestibility or hydrolysis of different lignocellulosic biomass and produce simple sugars that further can be used for various value-added products production (Sun et al. 2016). Despite all this, the present results suggest that one can partially replace costly commercial enzymes by crude enzyme extract. Also, the enzymes production in large scale by using this type of low-cost substrate can reduce the production cost. Furthermore, crude enzyme extract has the potential to be an environmentally friendly and helps in efficient saccharification process of biomass, which further can be used in different industries for various products production.

\section{CONCLUSIONS}

1. Significant synergies were found between the crude enzyme extracts from cellulolytic enzyme-producing bacterial strain and commercial cellulase in the enzymatic hydrolysis of pretreated and non-pretreated corn stover.

2. Compared to using commercial cellulase only, the mixed enzymes used for saccharification of AHP pretreated and non-pretreated corn stover increased the reducing sugar content at most by $23.3 \%$ and $94.7 \%$, respectively. Moreover, the highest amount of reducing sugars obtained from non-pretreated corn stover by mixed enzymes (316 $\mathrm{mg} \mathrm{g}^{-1}$ ) was almost as much from pretreated corn stover (318 to $321 \mathrm{mg}$ $\left.\mathrm{g}^{-1}\right)$.

3. Therefore, commercial enzymes and pretreatment requirements could be reduced to allow for more cost-effective production of different products. Also, there might be benefits in technological development and in real applications. 


\section{ACKNOWLEDGEMENTS}

This work was supported by a Natural Sciences and Engineering Research Council of Canada grant (Grant no. RGPIN-2017-05366) to WQ and a Priority Academic Program Development of Jiangsu Higher Education Institutions (PAPD) Scholarship to YW.

\section{REFERENCES CITED}

Akhlisah, Z. N., Yunus, R., Abidin, Z. Z., Lim, B. Y., and Kania, D. (2021).

"Pretreatment methods for an effective conversion of oil palm biomass into sugars and high-value chemicals," Biomass and Bioenergy 144, article no. 105901. DOI: 10.1016/j.biombioe.2020.105901

Arantes, V., and Saddler, J. N. (2010). "Access to cellulose limits the efficiency of enzymatic hydrolysis: The role of amorphogenesis," Biotechnol Biofuels 3, 1-11. DOI: $10.1186 / 1754-6834-3-1$

Avci, U., Zhou, X., Pattathil, S., da Costa Sousa, L., Hahn, M. G., Dale, B., Xu, Y., and Balan, V. (2019). "Effects of extractive ammonia pretreatment on the ultrastructure and glycan composition of corn stover," Front. Energy Res. 7, 1-12. DOI: 10.3389/fenrg.2019.00085

Banerjee, G., Car, S., Scott-Craig, J. S., Hodge, D. B., and Walton, J. D. (2011). "Alkaline peroxide pretreatment of corn stover: Effects of biomass, peroxide, and enzyme loading and composition on yields of glucose and xylose," Biotechnol Biofuels 4, 1-15. DOI: 10.1186/1754-6834-4-16

Chapla, D., Divecha, J., Madamwar, D., and Shah, A. (2010). "Utilization of agroindustrial waste for xylanase production by Aspergillus foetidus MTCC 4898 under solid state fermentation and its application in saccharification," Biochem. Eng. J. 49, 361-369. DOI: 10.1016/j.bej.2010.01.012

Chaturvedi, V., and Verma, P. (2013). "An overview of key pretreatment processes employed for bioconversion of lignocellulosic biomass into biofuels and value added products," 3 Biotech 3, 415-431. DOI: 10.1007/s13205-013-0167-8

Dahadha, S., Amin, Z., Abbas, A., Lakeh, B., and Elbeshbishy, E. (2017). "Evaluation of different pretreatment processes of lignocellulosic biomass for enhanced biomethane production," Energy Fuels 31(10), 10335-10347. DOI:

10.1021/acs.energyfuels.7b02045

Dutra, E. D., Santos, F. A., Alencar, B. R. A., Reis, A. L. S., de Souza, R. de F. R., Aquino, K. A. da S., Morais, M. A., and Menezes, R. S. C. (2018). "Alkaline hydrogen peroxide pretreatment of lignocellulosic biomass: Status and perspectives," Biomass Convers Biorefinery 8, 225-234. DOI: 10.1007/s13399-017-0277-3

Ferraz, L. J. A. A., Souza, L. O., Soares, G. A., Coutinho, J. P., de Oliveira, J. R., AguiarOliveira, E., and Franco, M. (2018). "Enzymatic saccharification of lignocellulosic residues using cellulolytic enzyme extract produced by Penicillium roqueforti ATCC 10110 cultivated on residue of yellow mombin fruit," Bioresour. Technol. 248, 214220. DOI: 10.1016/j.biortech.2017.06.048

Goyal, V., Mittal, A., Bhuwal, A. K., Singh, G., Yadav, A., and Aggarwal, N. K. (2014). "Parametric optimization of cultural conditions for carboxymethyl cellulase production using pretreated rice straw by Bacillus sp. 313SI under stationary and shaking conditions," Biotechnol. Res. Int. 2014, 1-7. DOI: 10.1155/2014/651839 
Guo, H., Chen, H., Fan, L., Linklater, A., Zheng, B., Jiang, D., and Qin, W. (2017). "Enzymes produced by biomass-degrading bacteria can efficiently hydrolyze algal cell walls and facilitate lipid extraction," Renew Energy 109, 195-201. DOI: 10.1016/j.renene.2017.03.025

Hendriks, A. T. W. M., and Zeeman, G. (2009). "Pretreatments to enhance the digestibility of lignocellulosic biomass," Bioresour. Technol. 100, 10-18. DOI: 10.1016/j.biortech.2008.05.027

Hu, J., Arantes, V., Pribowo, A., and Saddler, J. N. (2013). "The synergistic action of accessory enzymes enhances the hydrolytic potential of a 'cellulase mixture' but is highly substrate specific," Biotechnol Biofuels 6, 1. DOI: 10.1186/1754-6834-6-112

Isikgor, F. H., and Becer, C. R. (2015). "Lignocellulosic biomass: A sustainable platform for the production of bio-based chemicals and polymers," Polym. Chem. 6, 44974559. DOI: $10.1039 / \mathrm{c5py00263j}$

Jönsson, L. J., and Martín, C. (2016). "Pretreatment of lignocellulose: Formation of inhibitory by-products and strategies for minimizing their effects," Bioresour. Technol. 199, 103-112. DOI: 10.1016/j.biortech.2015.10.009

Kaur, A., Singh, A., Dua, A., and Mahajan, R. (2017). "Cost-effective and concurrent production of industrially valuable xylano-pectinolytic enzymes by a bacterial isolate Bacillus pumilus AJK," Prep. Biochem. Biotechnol. 47, 8-18. DOI: 10.1080/10826068.2016.1155059

Kim, Y.-K., Lee, S.-C., Cho, Y.-Y., Oh, H.-J., and Ko, Y. H. (2012). "Isolation of cellulolytic Bacillus subtilis strains from agricultural environments," ISRN Microbiol. 2012, 1-9. DOI: 10.5402/2012/650563

Kocabaş, S. D., Güder, S., and Özben, N. (2015). "Purification strategies and properties of a low-molecular weight xylanase and its application in agricultural waste biomass hydrolysis," J. Mol. Catal. B Enzym. 115, 66-75. DOI:10.1016/j.molcatb.2015.01.012

Lawrence, R., Kumar, Y., Kumar, S. A., and Satendra, S. (2015). "Production and optimization of xylanase by thermophilic Bacillus sp. isolated from soil," J. Pure Appl. Microbiol. 9, 1117-1128.

Li, C., Cheng, G., Balan, V., Kent, M. S., Ong, M., Chundawat, S. P. S., Sousa, L. da C., Melnichenko, Y. B., Dale, B. E., Simmons, B. A., and Singh, S. (2011). "Influence of physico-chemical changes on enzymatic digestibility of ionic liquid and AFEX pretreated corn stover," Bioresour. Technol. 102, 6928-6936. DOI: 10.1016/j.biortech.2011.04.005

Liu, C., Van Der Heide, E., Wang, H., Li, B., Yu, G., and Mu, X. (2013). "Alkaline twinscrew extrusion pretreatment for fermentable sugar production," Biotechnol. Biofuels 6, 1-11. DOI: 10.1186/1754-6834-6-97

Maki, M. L., Idrees, A., Leung, K. T., and Qin, W. (2012). "Newly isolated and characterized bacteria with great application potential for decomposition of lignocellulosic biomass," J. Mol. Microbiol. Biotechnol. 22, 156-166. DOI: $10.1159 / 000341107$

Martín, C., De Moraes Rocha, G. J., Dos Santos, J. R. A, De Albuquerque Wanderley, M. C., and Gouveia, E. R. (2012). "Enzyme loading dependence of cellulose hydrolysis of sugarcane bagasse," Quim. Nova 35, 1927-1930. DOI: 10.1590/S010040422012001000007

Mensah, M. B., Jumpah, H., Boadi, N. O., and Awudza, J. A. M. (2021). "Assessment of quantities and composition of corn stover in Ghana and their conversion into bioethanol," Sci. African 12, article no. e00731. DOI: 10.1016/j.sciaf.2021.e00731 
Miller, G. L. (1959). "Use of dinitrosalicylic acid reagent for determination of reducing sugar," Anal. Chem. 31, 426-428. DOI: 10.1021/ac60147a030

Ostadjoo, S., Hammerer, F., Dietrich, K., Dumont, M. J., Friscic, T., and Auclair, K. (2019). "Effcient enzymatic hydrolysis of biomass hemicellulose in the absence of bulkwater," Molecules 24, 1-12. DOI: 10.3390/molecules24234206

Paudel, Y. P., Lin, C., Shen, Z., Qin, W. (2015). "Characterization of pectin depolymerising exo polygalacturonase by Bacillus sp. HD2 isolated from the gut of Apis mellifera L.," Microbiol Discov 3:2. DOI: 10.7243/2052-6180-3-2

Prajapati, A. S., Panchal, K. J., Pawar, V. A., Noronha, M. J., Patel, D. H., and Subramanian R. B. (2018). "Review on cellulase and xylanase engineering for biofuel production," Ind. Biotechnol. 14, 38-44. DOI: 10.1089/ind.2017.0027

Rajendran, K., Drielak, E., Sudarshan Varma, V., Muthusamy, S., and Kumar, G. (2018). "Updates on the pretreatment of lignocellulosic feedstocks for bioenergy productionA review," Biomass Convers. Biorefinery 8, 471-483. DOI: 10.1007/s13399-0170269-3

Sadhu, S., and Maiti, T. K. (2013). "Cellulase production by bacteria: A review," Br. Microbiol. Res. J. 3, 235-258.

Shrestha, S., Mokale, A. L., Zhang, J., and Qin, W. (2020). "Different facets of lignocellulosic biomass including pectin and its perspectives," Waste and Biomass Valorization," DOI: 10.1007/s12649-020-01305-w

Singh, R., Varma, A. J., Seeta Laxman, R., and Rao, M. (2009). "Hydrolysis of cellulose derived from steam exploded bagasse by Penicillium cellulases: Comparison with commercial cellulase," Bioresour. Technol. 100, 6679-6681. DOI: 10.1016/j.biortech.2009.07.060

Sun, S., Sun, S., Cao, X., and Sun, R. (2016). "The role of pretreatment in improving the enzymatic hydrolysis of lignocellulosic materials," Bioresour. Technol. 199, 49-58. DOI: 10.1016/j.biortech.2015.08.061

Thatoi, H., Das, S., Mishra, J., Rath, B. P., and Das, N. (2014). "Bacterial chromate reductase, a potential enzyme for bioremediation of hexavalent chromium: A review," J. Environ. Manag. 146, 383-399. DOI: 10.1016/j.jenvman.2014.07.014

Vilanova, C., Marco, G., Domínguez-Escribà, L., Genovés, S., Sentandreu, V., Bataller, E., Ramón, D., and Porcar, M. (2012). "Bacteria from acidic to strongly alkaline insect midguts: Potential sources of extreme cellulolytic enzymes," Biomass and Bioenergy 45, 288-294. DOI: 10.1016/j.biombioe.2012.06.017

Wu, Y., Guo, H., Rahman, M. S., Chen, X., Zhang, J., Liu, Y., and Qin, W. (2021). "Biological pretreatment of corn stover for enhancing enzymatic hydrolysis using Bacillus sp. P3," Bioresour. Bioprocess 8. DOI: 10.1186/s40643-021-00445-8

Xu, N., Zhang, W., Ren, S., Liu, F., Zhao, C., Liao, H., Xu, Z., Huang, J., Li, Q., Tu, Y., Yu, B., Wang, Y., Jiang, J., Qin, J., and Peng, L. (2012). "Hemicelluloses negatively affect lignocellulose crystallinity for high biomass digestibility under $\mathrm{NaOH}$ and $\mathrm{H}_{2} \mathrm{SO}_{4}$ pretreatments in Miscanthus," Biotechnol. Biofuels 5, 1-12. DOI: 10.1186/1754-6834-5-58

Zhang, H., Han, L., and Dong, H. (2021a). "An insight to pretreatment, enzyme adsorption and enzymatic hydrolysis of lignocellulosic biomass: Experimental and modeling studies," Renew. Sustain. Energy Rev. 140, article no. 110758. DOI: 10.1016/j.rser.2021.110758

Zhang, P., Su, R., Duan, Y., Cui, M., Huang, R., Qi, W., He, Z., and Thielemans, W. (2021b). "Synergy between endo/exo-glucanases and expansin enhances enzyme 
adsorption and cellulose conversion," Carbohydr. Polym. 253, article no. 117287. DOI: 10.1016/j.carbpol.2020.117287

Zhang, Z., Liu, J. L., Lan, J. Y., Duan, C. J., Ma, Q. S., and Feng, J. X. (2014).

"Predominance of Trichoderma and Penicillium in cellulolytic aerobic filamentous fungi from subtropical and tropical forests in China, and their use in finding highly efficient $\beta$-glucosidase," Biotechnol. Biofuels 7, 1-14.

DOI: $10.1186 / 1754-6834-7-107$

Article submitted: October 6, 2021; Peer review completed: November 30, 2021;

Revised version received and accepted: December 25, 2021; Published: January 6, 2022.

DOI: 10.15376/biores.17.1.1301-1318 


\section{APPENDIX}

Table S1. CMCase and Xylanase Activity in Strains A0, AS2B, and CH20S1 Using Non-pretreated Corn Stover as the Substrate in Submerged Fermentation with Shaking for $144 \mathrm{~h}$ at $37^{\circ} \mathrm{C}$

\begin{tabular}{|c|c|c|c|c|c|c|}
\hline \multirow{2}{*}{ Time (h) } & \multicolumn{3}{|c|}{ CMCase (U mL-1) } & \multicolumn{3}{c|}{ Xylanase (U mL- ${ }^{-1}$} \\
\cline { 2 - 7 } & A0 & CH20S1 & AS2B & A0 & CH20S1 & AS2B \\
\hline $\mathbf{0}$ & 0 & 0 & 0 & 0 & 0 & 0 \\
\hline $\mathbf{1 2}$ & $2.11 \pm 0.14$ & $1.96 \pm 0.19$ & $2.57 \pm 0.17$ & $20.26 \pm 0.56$ & $29.44 \pm 0.18$ & $26.65 \pm 0.94$ \\
\hline $\mathbf{2 4}$ & $1.93 \pm 0.07$ & $1.89 \pm 0.11$ & $2.11 \pm 0.25$ & $14.59 \pm 1.09$ & $23.15 \pm 1.36$ & $21.68 \pm 0.97$ \\
\hline $\mathbf{4 8}$ & $1.66 \pm 0.07$ & $1.78 \pm 0.11$ & $1.63 \pm 0.13$ & $7.63 \pm 0.11$ & $10.02 \pm 0.40$ & $8.63 \pm 0.63$ \\
\hline $\mathbf{7 2}$ & $1.54 \pm 0.04$ & $1.75 \pm 0.16$ & $1.55 \pm 0.04$ & $7.61 \pm 1.69$ & $9.69 \pm 0.64$ & $7.56 \pm 1.01$ \\
\hline $\mathbf{9 6}$ & $1.37 \pm 0.16$ & $1.62 \pm 0.09$ & $1.50 \pm 0.02$ & $6.39 \pm 1.12$ & $9.27 \pm 0.49$ & $5.87 \pm 1.05$ \\
\hline $\mathbf{1 2 0}$ & $0.86 \pm 0.09$ & $1.53 \pm 0.20$ & $1.46 \pm 0.05$ & $1.53 \pm 1.36$ & $5.70 \pm 0.18$ & $4.63 \pm 1.44$ \\
\hline $\mathbf{1 4 4}$ & $0.89 \pm 0.13$ & $1.47 \pm 0.19$ & $1.42 \pm 0.10$ & $0.34 \pm 0.70$ & $3.29 \pm 1.40$ & $2.79 \pm 0.49$ \\
\hline
\end{tabular}

Table S2. Optimal Temperature for CMCase and Xylanase Activities Produced by Strains A0, AS2B, and $\mathrm{CH} 20 \mathrm{~S} 1$

\begin{tabular}{|c|l|l|l|l|l|l|}
\hline \multirow{2}{*}{$\begin{array}{c}\text { Temp } \\
\left({ }^{\circ} \mathbf{C}\right)\end{array}$} & \multicolumn{3}{|c|}{ CMCase (Relative Activity \%) } & \multicolumn{3}{c|}{ Xylanase (Relative Activity \%) } \\
\cline { 2 - 7 } & A0 & AS2B & CH20S1 & A0 & AS2B & CH20S1 \\
\hline $\mathbf{4 0}$ & $63.07 \pm 0.80$ & $48.27 \pm 1.39$ & $41.33 \pm 3.61$ & $32.97 \pm 1.19$ & $61.41 \pm 4.46$ & $54.74 \pm 5.11$ \\
\hline $\mathbf{4 5}$ & $71.02 \pm 0.80$ & $54.85 \pm 0.94$ & $53.06 \pm 4.33$ & $44.20 \pm 1.71$ & $62.61 \pm 2.42$ & $67.71 \pm 1.23$ \\
\hline $\mathbf{5 0}$ & $76.70 \pm 0.99$ & $84.73 \pm 0.33$ & $84.18 \pm 3.43$ & $65.82 \pm 4.61$ & $100.00 \pm 1.69$ & $93.52 \pm 8.11$ \\
\hline $\mathbf{5 5}$ & $100.00 \pm 4.82$ & $100.00 \pm 3.32$ & $100.00 \pm 2.72$ & $71.14 \pm 0.17$ & $90.24 \pm 0.48$ & $94.14 \pm 0.53$ \\
\hline $\mathbf{6 0}$ & $90.91 \pm 4.82$ & $93.59 \pm 0.00$ & $97.96 \pm 1.61$ & $100.00 \pm 8.29$ & $76.27 \pm 2.12$ & $100.00 \pm 2.11$ \\
\hline $\mathbf{6 5}$ & $86.36 \pm 1.61$ & $82.76 \pm 2.79$ & $94.89 \pm 1.44$ & $63.82 \pm 3.68$ & $54.95 \pm 3.82$ & $52.62 \pm 2.12$ \\
\hline $\mathbf{7 0}$ & $81.95 \pm 0.19$ & $79.31 \pm 0.69$ & $81.63 \pm 4.33$ & $30.92 \pm 5.46$ & $49.39 \pm 5.31$ & $52.49 \pm 2.99$ \\
\hline $\mathbf{7 5}$ & $75.57 \pm 2.41$ & $49.75 \pm 3.48$ & $62.76 \pm 5.05$ & $23.79 \pm 2.56$ & $25.97 \pm 2.33$ & $42.52 \pm 7.23$ \\
\hline $\mathbf{8 0}$ & $44.88 \pm 4.02$ & $45.32 \pm 2.79$ & $28.57 \pm 1.27$ & $22.46 \pm 0.56$ & $22.82 \pm 1.27$ & $29.80 \pm 0.17$ \\
\hline
\end{tabular}

Table S3. Optimal pH for CMCase and Xylanase Activities Produced by Strains $\mathrm{A} 0, \mathrm{AS} 2 \mathrm{~B}$, and $\mathrm{CH} 20 \mathrm{~S} 1$

\begin{tabular}{|l|l|l|l|l|l|l|}
\hline \multirow{2}{*}{ pH } & \multicolumn{3}{|c|}{ CMCase (Relative Activity \%) } & \multicolumn{3}{c|}{ Xylanase (Relative Activity \%) } \\
\cline { 2 - 7 } & A0 & AS2B & CH20S1 & A0 & AS2B & CH20S1 \\
\hline $\mathbf{4 . 0}$ & $72.47 \pm 3.97$ & $57.56 \pm 0.82$ & $65.00 \pm 1.77$ & $62.49 \pm 2.75$ & $63.05 \pm 1.26$ & $60.34 \pm 0.76$ \\
\hline $\mathbf{4 . 5}$ & $77.53 \pm 4.77$ & $79.65 \pm 0.82$ & $93.75 \pm 1.77$ & $85.99 \pm 0.33$ & $68.30 \pm 1.77$ & $76.49 \pm 2.85$ \\
\hline $\mathbf{5 . 0}$ & $95.51 \pm 4.77$ & $100.00 \pm 3.29$ & $100.00 \pm 3.53$ & $97.89 \pm 1.10$ & $100.00 \pm 1.26$ & $100.00 \pm 3.52$ \\
\hline $\mathbf{5 . 5}$ & $100.00 \pm 1.58$ & $89.53 \pm 1.64$ & $98.13 \pm 2.65$ & $100.00 \pm 0.55$ & $97.89 \pm 1.01$ & $97.37 \pm 1.52$ \\
\hline $\mathbf{6 . 0}$ & $92.13 \pm 1.58$ & $73.83 \pm 0.82$ & $94.37 \pm 2.65$ & $94.86 \pm 1.43$ & $93.96 \pm 3.67$ & $95.18 \pm 2.95$ \\
\hline $\mathbf{6 . 5}$ & $69.10 \pm 2.38$ & $52.32 \pm 8.22$ & $55.00 \pm 1.76$ & $71.44 \pm 2.64$ & $68.31 \pm 4.30$ & $58.18 \pm 0.38$ \\
\hline $\mathbf{7 . 0}$ & $63.48 \pm 0.79$ & $44.77 \pm 2.46$ & $49.37 \pm 0.88$ & $69.81 \pm 0.77$ & $55.43 \pm 6.45$ & $49.56 \pm 3.23$ \\
\hline $\mathbf{7 . 5}$ & $46.07 \pm 1.58$ & $42.44 \pm 0.82$ & $48.75 \pm 3.53$ & $64.82 \pm 0.55$ & $50.87 \pm 1.13$ & $46.86 \pm 5.33$ \\
\hline $\mathbf{8 . 0}$ & $37.64 \pm 2.38$ & $42.44 \pm 2.47$ & $46.87 \pm 0.88$ & $34.86 \pm 4.40$ & $22.50 \pm 0.13$ & $34.01 \pm 3.14$ \\
\hline
\end{tabular}


Table S4. Saccharification of Non-pretreated (a), AHP Pretreated (b), and $\mathrm{H}_{2} \mathrm{SO}_{4}$ Pretreated (c) Corn Stover Using Crude Enzymes Produced by Strains A0, AS2B, and $\mathrm{CH} 20 \mathrm{~S} 1$

a)

\begin{tabular}{|l|l|l|l|l|l|l|}
\hline & $0 \mathrm{~h}$ & $12 \mathrm{~h}$ & $24 \mathrm{~h}$ & $36 \mathrm{~h}$ & $48 \mathrm{~h}$ & $60 \mathrm{~h}$ \\
\hline $\mathrm{A} 0$ & $21.57 \pm 2.32$ & $39.73 \pm 6.91$ & $45.79 \pm 6.35$ & $49.56 \pm 4.93$ & $58.97 \pm 3.45$ & $63.28 \pm 5.39$ \\
\hline $\mathrm{CH} 20 \mathrm{~S} 1$ & $24.73 \pm 2.48$ & $45.57 .166 \pm$ & $45.98 \pm 4.16$ & $56.73 \pm 3.31$ & $64.01 \pm 3.46$ & $71.29 \pm 6.32$ \\
\hline AS2B & $26.07 \pm 2.86$ & $40.94 \pm 2.25$ & $40.52 \pm 3.04$ & $54.78 \pm 4.53$ & $63.65 \pm 3.06$ & $70.20 \pm 2.23$ \\
\hline Buffer & $8.28 \pm 0.14$ & $8.34 \pm 0.36$ & $8.95 \pm 0.64$ & $8.77 \pm 0.46$ & $8.16 \pm 0.48$ & $8.89 \pm 0.28$ \\
\hline
\end{tabular}

b)

\begin{tabular}{|l|l|l|l|l|l|l|}
\hline & $0 \mathrm{~h}$ & $12 \mathrm{~h}$ & $24 \mathrm{~h}$ & $36 \mathrm{~h}$ & $48 \mathrm{~h}$ & $60 \mathrm{~h}$ \\
\hline $\mathrm{A} 0$ & $22.44 \pm 1.40$ & $38.43 \pm 1.98$ & $40.46 \pm 1.07$ & $46.04 \pm 2.56$ & $47.38 \pm 1.93$ & $52.59 \pm 3.51$ \\
\hline CH20S1 & $19.12 \pm 0.18$ & $39.889 \pm 4.29$ & $45.59 \pm 4.58$ & $53.53 \pm 6.94$ & $56.85 \pm 7.73$ & $62.88 \pm 4.51$ \\
\hline AS2B & $20.09 \pm 1.45$ & $36.73 \pm 1.53$ & $47.013 \pm 2.69$ & $51.38 \pm 2.80$ & $51.22 \pm 2.71$ & $49.88 \pm 1.17$ \\
\hline Buffer & $7.18 \pm 0.37$ & $7.552 \pm 0.50$ & $9.01 \pm 1.011$ & $10.34 \pm 0.78$ & $10.34 \pm 0.78$ & $11.39 \pm 1.01$ \\
\hline
\end{tabular}

c)

\begin{tabular}{|l|l|l|l|l|l|l|}
\hline & $0 \mathrm{~h}$ & $12 \mathrm{~h}$ & $24 \mathrm{~h}$ & $36 \mathrm{~h}$ & $48 \mathrm{~h}$ & $60 \mathrm{~h}$ \\
\hline $\mathrm{A} 0$ & $21.33 \pm 3.69$ & $31.94 \pm 1.68$ & $33.08 \pm 3.44$ & $36.57 \pm 6.56$ & $44.40 \pm 4.56$ & $48.83 \pm 5.06$ \\
\hline CH20S1 & $23.70 \pm 2.26$ & $34.20 \pm 5.49$ & $36.87 \pm 7.44$ & $44.13 \pm 7.04$ & $51.44 \pm 3.43$ & $54.84 \pm 6.99$ \\
\hline AS2B & $22.24 \pm 1.89$ & $28.74 \pm 2.26$ & $40.03 \pm 6.14$ & $43.50 \pm 4.17$ & $48.59 \pm 5.86$ & $52.11 \pm 4.95$ \\
\hline Buffer & $7.79 \pm 0.14$ & $8.40 \pm 0.39$ & $9.07 \pm 0.69$ & $9.62 \pm 1.73$ & $8.09 \pm 0.23$ & $9.85 \pm 1.31$ \\
\hline
\end{tabular}


Table S5. Saccharification of Non-pretreated (a), AHP Pretreated (b), and $\mathrm{H}_{2} \mathrm{SO}_{4}$ Pretreated (c) Corn Stover using Bacterial Enzyme Extracts with Different Additions of Commercial Cellulases

a)

\begin{tabular}{|c|l|l|l|l|}
\hline Time $(\mathrm{h})$ & $\begin{array}{l}\text { 4 FPU of } \\
\text { commercial } \\
\text { cellulase+DCE }\end{array}$ & $\begin{array}{l}\text { 8 FPU of } \\
\text { commercial } \\
\text { cellulase+DCE }\end{array}$ & $\begin{array}{l}\text { 12 FPU of } \\
\text { commercial } \\
\text { cellulase+DCE }\end{array}$ & $\begin{array}{l}\text { 20 FPU of } \\
\text { commercial } \\
\text { cellulase+DCE }\end{array}$ \\
\hline 0 & $40.89 \pm 6.12$ & $28.09 \pm 1.38$ & $15.37 \pm 1.01$ & $11.61 \pm 1.88$ \\
\hline 12 & $122.91 \pm 6.87$ & $171.81 \pm 5.15$ & $197.65 \pm 5.15$ & $239.78 \pm 6.11$ \\
\hline 24 & $130.28 \pm 6.42$ & $179.19 \pm 1.72$ & $223.17 \pm 7.42$ & $245.93 \pm 7.42$ \\
\hline 36 & $138.89 \pm 5.06$ & $198.57 \pm 3.03$ & $229.02 \pm 12.02$ & $251.47 \pm 18.23$ \\
\hline 48 & $148.74 \pm 15.16$ & $203.49 \pm 17.57$ & $230.86 \pm 5.15$ & $263.77 \pm 2.80$ \\
\hline 60 & $149.66 \pm 15.45$ & $205.027 \pm 8.58$ & $258.54 \pm 5.15$ & $283.46 \pm 13.74$ \\
\hline 72 & $144.34 \pm 8.58$ & $241.01 \pm 4.24$ & $271.46 \pm 1.72$ & $317.59 \pm 8.18$ \\
\hline
\end{tabular}

b)

\begin{tabular}{|c|l|l|l|l|}
\hline Time $(\mathrm{h})$ & $\begin{array}{l}\text { 4 FPU of } \\
\text { commercial } \\
\text { cellulase+DCE }\end{array}$ & $\begin{array}{l}\text { 8 FPU of } \\
\text { commercial } \\
\text { cellulase+DCE }\end{array}$ & $\begin{array}{l}\text { 12 FPU of } \\
\text { commercial } \\
\text { cellulase+DCE }\end{array}$ & $\begin{array}{l}\text { 20 FPU of } \\
\text { commercial } \\
\text { cellulase+DCE }\end{array}$ \\
\hline 0 & $14.96 \pm 0.87$ & $14.15 \pm 1.01$ & $19.89 \pm 0.37$ & $13.99 \pm 0.84$ \\
\hline 12 & $130.16 \pm 3.43$ & $178.73 \pm 6.87$ & $154.44 \pm 3.43$ & $164.16 \pm 4.86$ \\
\hline 24 & $171.44 \pm 3.43$ & $184.79 \pm 1.71$ & $164.97 \pm 5.05$ & $167.79 \pm 8.58$ \\
\hline 36 & $230.94 \pm 2.53$ & $206.65 \pm 1.72$ & $170.63 \pm 5.06$ & $177.92 \pm 7.37$ \\
\hline 48 & $272.22 \pm 15.45$ & $242.67 \pm 7.01$ & $179.54 \pm 7.42$ & $200.58 \pm 3.43$ \\
\hline 60 & $315.93 \pm 8.58$ & $298.93 \pm 8.58$ & $249.15 \pm 10.30$ & $247.94 \pm 1.72$ \\
\hline 72 & $320.65 \pm 1.72$ & $302.57 \pm 6.87$ & $260.08 \pm 5.15$ & $260.08 \pm 8.58$ \\
\hline
\end{tabular}

c)

\begin{tabular}{|c|l|l|l|l|}
\hline Time $(\mathrm{h})$ & $\begin{array}{l}\text { 4 FPU of } \\
\text { commercial } \\
\text { cellulase+DCE }\end{array}$ & $\begin{array}{l}\text { 8 FPU of } \\
\text { commercial } \\
\text { cellulase+DCE }\end{array}$ & $\begin{array}{l}\text { 12 FPU of } \\
\text { commercial } \\
\text { cellulase+DCE }\end{array}$ & $\begin{array}{l}\text { 20 FPU of } \\
\text { commercial } \\
\text { cellulase+DCE }\end{array}$ \\
\hline 0 & $43.37 \pm 2.32$ & $43.69 \pm 1.46$ & $68.63 \pm 0.84$ & $49.36 \pm 4.92$ \\
\hline 12 & $109.92 \pm 5.61$ & $123.68 \pm 8.53$ & $160.11 \pm 17.06$ & $97.78 \pm 12.22$ \\
\hline 24 & $147.16 \pm 10.58$ & $131.37 \pm 12.02$ & $205.44 \pm 11.89$ & $128.95 \pm 12.62$ \\
\hline 36 & $154.44 \pm 4.86$ & $147.16 \pm 3.43$ & $222.44 \pm 13.74$ & $139.87 \pm 0.00$ \\
\hline 48 & $162.94 \pm 1.72$ & $150.80 \pm 12.02$ & $235.39 \pm 13.37$ & $147.16 \pm 4.86$ \\
\hline 60 & $179.94 \pm 5.15$ & $166.58 \pm 12.02$ & $265.83 \pm 1.72$ & $161.73 \pm 10.30$ \\
\hline 72 & $181.73 \pm 0.00$ & $183.58 \pm 0.00$ & $315.90 \pm 24.04$ & $162.25 \pm 3.71$ \\
\hline
\end{tabular}

Note: Saccharification was performed at $55^{\circ} \mathrm{C}, \mathrm{pH} 5.0$, with $200 \mathrm{rpm}$ for $72 \mathrm{~h}$, using a substrate concentration of $1 \%$ and reducing sugar is calculated in $\mathrm{mg} \mathrm{g}^{-1}$. 